\section{Questión}

Periodismo / Comunicación ISSN 1669-6581
- Av. $44 \mathrm{~N}^{\circ} 676,1^{\circ}$ piso

CP 1900 - La Plata - Argentina

www.perio.unlp.edu.ar/question

Otra manera de tratarnos

Sandra Martinez

DOI: https://doi.org/10.24215/16696581e336

\title{
Otra manera de tratarnos
}

\section{another way to treat us}

Sandra Martinez / librosvillaelisa@gmail.com

Periodista, Escritora, Librera

Cuando el jueves 19 de marzo a las 20 horas bajé las persianas de mi librería en Villa Elisa, no sabía que a casi un mes, todavía estarían igual de cerradas. A veces voy a limpiar, a buscar libros para llevar a las casas de los clientes o simplemente a estar un rato. Camino, doy vueltas, acomodo las estanterías, paso la mano por las tapas y me pregunto si sobre "Los Matemáticos" de 5to. vivirá alguna bacteria o virus capaz de arrebatarnos todas las seguridades de un golpe.

Los libros de los más chicos son los que más pena me dan, no sé porqué pero los siento como abandonados, lastimados en la inutilidad del estarse quietos y silenciosos.

Hace pocos días comencé con el delivery y es una experiencia... en una casa, que tenía un almacén en penumbras y semivacío adelante, me pagó los 1000 pesos que salía el libro de inglés encargado, un abuelo de manos arrugadas que agradeció agradecidamente (así de fervoroso) el envío como si se tratase un milagro.

En otras casas, quizás acostumbradas a recibir encargos, pizzas etc, el trámite es sencillo y cordial, pero el abuelo en cuestión estaba realmente asombrado que los libros llegasen a las casas de ese barrio tan humilde.

Otra postal. En las móviles cuadras del barrio El Rincón que se extiende como un Macondo orgánico, llevé otro encargo a una de las últimas casas donde ya todo era llanura y perros. Al 
escuchar el auto salió la familia en pleno a recibirme. Los chicos gritaban "¡ilos libros, los libros!!" y pensé qué contentos estarían algunos maestros que conozco. Los papás jóvenes, lindos y artesanales, salieron con las tazas del desayuno a la vereda. La vida no debe ser fácil por esos andurriales pero esa mañana de sol estaban todos iluminados y preciosos. Y pensé que estaba muy bien conocer las casas de los clientes, que era un lindo gesto saber de dónde vienen, cuánto cuesta a veces salir del barrio, tomarse un colectivo o agarrar el auto para llegar al negocio. Y que entonces, uno no puede menos que atenderlos con una sonrisa y obsequiarle un mate. Claro ahora ya mate no, pero hay que pensar otra forma de compartir.

Hace poco, ¡bah! en realidad unos meses (y es que la pandemia ha desarrollado otra manera de tratarnos con el tiempo) se me ocurrió que los libreros independientes, los de barrio, tendríamos que becar, con ayuda del Estado o de las editoriales, a algunos lectores. Es decir elegir por ejemplo un lector (joven, niño, anciano, no importa la edad) que sepamos amante de la lectura y con algunas imposibilidades económicas de tener los libros que más le interesan, sería "becado" para recibir en forma gratuita tres libros en un mes. El siguiente mes la beca sería para otro y así.

Creo que haríamos feliz a mucha gente. $Y$ si, casi no se pueden pagar los gastos fijos y debo plata etc. etc. (no voy a abundar en datos que todos sufrimos) pero es una cosa seria hacer feliz a otro.

Sigo repartiendo libros casa por casa. La tarde anterior hago un plano busco proximidades y afinidades. Esta mal decirlo pero qué placer me dio llevarle el libro de Borges a Almendra que vive en un departamento y me vio por el balcón. Estaba como todo el mundo, creo yo, en piyama y pensé seriamente que tampoco estaría mal espejarme con mis clientes y repartir en piyama y barbijo. En fin, sumo días de cuarentena y recomiendo a quién pregunta que "Nuestra parte de noche" es el último libro que me dejo muda de palabras y gritos.

Por hoy ya está. 